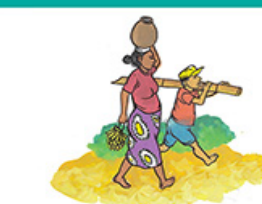

\title{
The rural roots of the rise of the Justice and Development Party in Turkey
}

\section{Burak Gürel, Bermal Küçük \& Sercan Taş}

To cite this article: Burak Gürel, Bermal Küçük \& Sercan Taș (2019) The rural roots of the rise of the Justice and Development Party in Turkey, The Journal of Peasant Studies, 46:3, 457-479, DOI: 10.1080/03066150.2018.1552264

To link to this article: https://doi.org/10.1080/03066150.2018.1552264

曲 Published online: 24 Jan 2019.

Submit your article to this journal $\pi$

Lll Article views: 772

Q View related articles $₫$

View Crossmark data \lceil

4 Citing articles: 2 View citing articles 


\title{
The rural roots of the rise of the Justice and Development Party in Turkey
}

\author{
Burak Gürel (D), Bermal Küçük and Sercan Taş \\ Department of Sociology, Koç University, Istanbul, Turkey
}

\begin{abstract}
This paper puts forward four main arguments regarding the persistence of significant rural support of the Justice and Development Party (Adalet ve Kalkınma Partisi, AKP) in Turkey since late 2002. Firstly, since the previous coalition government implemented the harshest neoliberal measures in the agricultural sector, small farmers do not directly associate neoliberal assault with the AKP administration. Secondly, villagers have utilized both the ballot box and direct action in order to bargain with the AKP. Thirdly, although the AKP government did not fundamentally depart from neoliberalism, the return of agricultural subsidies, significant expansion of social assistance, and rapid infrastructure construction have secured a large rural following for the party. Finally, the AKP government has effectively used coercive methods to prevent the emergence of an emancipatory political alternative.
\end{abstract}

\section{KEYWORDS}

Authoritarian populism; emancipatory rural politics; social neoliberalism; AKP; Turkey

\section{Introduction}

The uninterrupted rule of Recep Tayyip Erdoğan's Justice and Development Party (Adalet ve Kalkınma Partisi, AKP hereafter), since the general election on 3 November 2002 represents the peak of Turkish Islamism. Over the last sixteen years, the AKP has significantly transformed the Turkish economy, society and politics. In the economic realm, the AKP privatized the great majority of the state-owned enterprises, completing the job that the (relatively) secular mainstream parties undertook since the 1980 s. $^{1}$ On the other hand, by supporting the Islamist bourgeoisie much more so than the secular bourgeoisie through various favoritisms, the AKP has made significant progress (although not yet completed) in altering the balance of power in favor of the Turkish bourgeoisie's Islamist wing (Balkan, Balkan, and Öncü 2015; Esen and Gümüşçü 2018). The AKP's transformation of Turkish society and politics runs much deeper than its economic performance. The ruling party has implemented an ambitious project of reconstructing the state and

CONTACT Burak Gürel $\square$ bgurel@ku.edu.tr; gurel.burak@gmail.com

Editorial Note: This paper is part of the 'JPS Forum on Authoritarian Populism and the Rural World', framed and introduced by lan Scoones and colleagues in their joint paper, 'Emancipatory Rural Politics: Confronting Authoritarian Populism', published in JPS in January 2018. The contributions to this forum will be published separately and in clusters in 2018 and 2019. This forum is one of the initial outcomes of the activities of the Emancipatory Rural Politics Initiative (ERPI, www.iss.nl/erpi).

${ }^{1}$ The value of privatized assets increased from 8.2 billion dollars between 1995 and 2003 (Somer 2016, 492) to 59.9 billion dollars between 2003 and 2017 (Diken 2018).

(c) 2019 Informa UK Limited, trading as Taylor \& Francis Group 
Table 1. AKP's estimated vote share (\%), 2007-2015

\begin{tabular}{lcccccc}
\hline & 2007 & 2009 & 2011 & 2014 & June 2015 & November 2015 \\
\hline Rural & $\mathbf{5 0 . 4 5}$ & $\mathbf{4 0 . 9 9}$ & $\mathbf{5 1 . 9 8}$ & $\mathbf{4 7 . 0 1}$ & $\mathbf{4 8 . 5 7}$ & $\mathbf{5 4 . 7 1}$ \\
Urban & 45.61 & 38.37 & 47.97 & 43.87 & 42.85 & 50.59 \\
Metropolitan & 44.06 & 40.22 & 44.59 & 39.32 & 39.02 & 42.91 \\
\hline
\end{tabular}

${ }^{a}$ The KONDA survey data define the rural area as an area with a population of less than 5000 people until the 2011 elections and with a population of less than 4000 people until the November 2015 elections. Vote shares include those who did not have a party preference and those intended not to vote at the time of the survey.

Source: KONDA Barometer Survey Estimates (2007-2015).

society on an Islamist basis. To this end, the government has considerably altered public education (Butler 2018); boosted the power of the Directorate of Religious Affairs (The Economist 2018); generously supported the schools and hospitals run by Islamist foundations (Demirtaş 2017); and suppressed the secular and leftist opposition. It is difficult to predict the future of Turkish Islamism. However, the AKP's uninterrupted rule and mass support over the last sixteen years are undeniably remarkable successes of the Islamist project, which therefore should be seriously investigated.

This paper analyzes the rural roots of the AKP's political power. Despite rapid urbanization, a quarter of Turkey's population is still rural (World Bank 2018). The AKP's vote share has been consistently higher in the countryside than in the cities (Table 1). The approval of the constitutional amendment in the referendum on 16 April 2017 established a super presidential system without checks and balances. The amendment was passed with a slight majority (51.4 percent), but the share of the yes vote in the rural areas was much higher, estimated to be between 56 percent (Konda 2017) and 62 percent (Yetkin 2017). The snap (parliamentary and presidential) elections on 24 June 2018 provide another evidence of this phenomenon. Erdoğan was elected to president by receiving 52.3 percent of the votes, more than 20 percent higher than his closest competitor. AKP got 42.5 percent of the popular vote, 20 percent higher than the second party.

This paper primarily focuses on the economic factors behind the AKP's strong support in the Turkish countryside for two main reasons. Firstly, the existing literature on Turkish politics has investigated the (strictly) cultural, ideological, and political factors behind the continuity of AKP power in greater detail than other factors. The AKP leadership's crafty use of a mixture of nationalist, Islamist, neo-Ottomanist, and developmentalist discourses; shifting alliances in national ${ }^{2}$ and international politics; ${ }^{3}$ portrayal of the (both right-wing

\footnotetext{
${ }^{2} \mathrm{~A}$ detailed analysis of the AKP's making and unmaking of political alliances since 2002 is beyond the scope of this paper, but a brief summary is in order. Based on its alliance with Fethullah Gülen's Islamist organization (which was strongly organized especially in the judiciary and security apparatuses of the state) and pro-Western liberals (who were strong in the media and intellectual circles) against the secular nationalists inside the military and civilian bureaucracy, which continued at least until the end of 2010, the AKP government completed a significant part of its Islamization agenda. AKP's relationship with liberal circles rapidly deteriorated, especially after the suppression of the Gezi protests in June 2013. Following the breakup of Turkish Islamism (between the AKP and Gülenists) at the end of 2013, AKP allied with a sizeable portion of the previously suppressed secular nationalists against the Gülenists. Similarly, AKP negotiated with the Kurdish movement during the so-called 'solution process' between 2012 and 2015. The ultra-nationalist Nationalist Action Party (Milliyetçi Hareket Partisi, MHP) repeatedly blamed AKP leadership for treason to the Turkish nation and state because of their participation in the solution process. AKP-MHP relations rapidly improved following the end of the solution process in 2015 and became an open partnership following the failed coup attempt (organized primarily by the Gülenists) on 15 June 2016. This partnership was instrumental in the passing of the constitutional amendment on 17 April 2017 and Erdoğan's reelection to presidency on 24 June 2018.

${ }^{3} \mathrm{~A}$ few examples may explain the AKP government's unending zigzags in international relations. The then Prime Minister Tayyip Erdoğan and Syrian president Bashar al-Assad openly celebrated their countries' close relations during meetings in 2008 and 2009. However, Turkey provided significant support to anti-Assad opposition during the civil war after 2011.
} 
and left-wing) opposition as treasonous; increasingly intensive use of coercive methods to deal with political dissent; and the resulting political polarization in Turkey have all been scrutinized in sufficient detail in the existing literature. ${ }^{4}$ Without denying the importance of these factors, this paper mainly investigates the policies of agricultural subsidization, social assistance, and infrastructure construction as important factors which account for the AKP's mass support in the countryside.

The second reason for this paper's exclusive focus on material factors stems from our disagreement with the great majority of the political opposition in Turkey concerning the nature of the AKP's rural policy. Interestingly, unlike the analyses of the AKP, which generally give primacy to cultural and ideological factors, economic analyses dominate discussions on rural Turkey's trajectory during the AKP period. The great majority of the opposition parties - including the center-left Republican People's Party (Cumhuriyet Halk Partisi, CHP) (CHP 2017; Yıldırım 2014), the pro-Kurdish People's Democratic Party (Halkların Demokratik Partisi, HDP) (Cumhuriyet April 21, 2015), socialist parties and organizations (Halkevleri 2010; ÖDP 2017; TKP 2007), and critical scholars (Alçın 2017; Günaydın 2009, 2016; Oral 2013) - believe that the AKP has waged a war against agriculture and farmers, with the aim of completely de-agrarianizing the country and thereby making it entirely dependent on agricultural imports. A significant portion of news reports published by the leftist and rightist (non-AKP) media paints a similar picture. ${ }^{5}$ We disagree with these claims. Though the AKP's agricultural policy is pro-capital and (by and large) neoliberal, its critics' singular emphasis on neoliberalism does not help much to explain its rural support. This critique also risks portraying rural people as staunch conservatives whose political behavior will not change, regardless of the changes in their living standards. We should avoid reducing the question of political hegemony to a narrow question of cultural values.

This paper offers an alternative to existing explanations by identifying the material basis of the AKP's rural support. It points to factors such as rural people's perception of government policies, changes in living standards, and bargains with the government (through street protests and the ballot box), as well as the resulting concessions they have secured.

This paper puts forward four main arguments. Firstly, we argue that since the previous coalition government (1999-2002) implemented the harshest neoliberal measures in the agricultural sector, small farmers do not directly associate neoliberal assault with the AKP administration. Secondly, the lower classes in rural areas have utilized both the ballot box and direct action to bargain with the AKP government. Thirdly, although the AKP government did not fundamentally depart from the neoliberal agricultural orientation (established by the previous government), it has adopted policies (in response to villagers' use of street protest and the ballot box) that have eased the pressure on small farmers and proletarianized villagers -to a certain extent- through the return of agricultural subsidies and the significant expansion of social assistance to low-income groups. Along with continuous economic growth and rapid infrastructural development (such as roads and

Escalating tensions between Russia and Turkey (due to their being on opposite sides of the Syrian war) resulted in the Turkish military's downing of a Russian military aircraft on the Syrian border on 24 November 2015. On 25 August 2018, less than three years after the crisis, Turkish Foreign Minister Mevlüt Çavuşoğlu claimed that Russia and Turkey were 'strategic partners.' However, the Turkish government has not stopped its efforts to weaken the Russian-backed Syrian regime. Similar examples can be given with regard to Turkey's relations with all major geopolitical actors since 2002.

${ }^{4}$ For examples of this large and growing body of literature, see Esmer 2019; Keyman 2014; Somer 2016.

${ }^{5}$ For examples of negative media coverage of agrarian change, see Büyüktaş 2016; Erboz 2017; Ertürk 2017. 
bridges), the AKP's limited economic redistribution has made both the neoliberal transformation and increasing right-wing authoritarianism more hegemonic. Finally, like all historical experiences of political hegemony utilizing the carrot-and-stick approach, the AKP government has also used increasingly more coercive methods against radical farmer organizations, labor unions, and the socialist left in order to prevent the emergence of an emancipatory (rural and urban) politics in Turkey.

This study combines fieldwork, archival research, quantitative analysis, and review of secondary sources. We conducted semi-structured interviews with 28 people (hazelnut producers, tea producers, and district political party representatives) in the cities of Ordu and Rize in the Eastern Black Sea region of Turkey in 2018. The interviewees included young and middle-aged males. Agriculture is the primary source of income for the majority of our respondents. Most respondents have secondary sources of income such as coffee houses or minibuses, with at least one pensioner family member and one family member employed in the non-farm sectors. We focused on the cases of Rize and Ordu for two main reasons. First, the AKP's vote share has been higher than the national average in these regions (especially in rural areas). Second, farmer complaints and protests in these regions have received widespread media coverage. Hence, Ordu and Rize are cases which exemplify the co-existence of both extreme criticism and extreme support for the government. In addition to fieldwork, we consulted the online archives of the local and national news media and the statistical data provided by various international and national agencies. We also reviewed the academic and policy literatures regarding the agricultural and social policies in Turkey.

This paper consists of eight sections. The second section examines the Turkish case from a comparative-historical perspective. The third section examines the period between 1995 and 2002 as a prelude to the rise of the AKP. The fourth section responds to whether or not the AKP has completely de-agrarianized Turkey and impoverished farmers. The fifth and sixth sections examine the AKP's engagement with (respectively) the hazelnut and tea producers of the Eastern Black Sea region. The seventh section responds to the question of whether or not environmental protests have led to any meaningful change in rural politics. The last section reiterates the main arguments of the paper and discusses their political implications for the future of emancipatory rural politics in Turkey.

\section{The AKP's rural mass support from a comparative-historical perspective}

The rise of the AKP is clearly a part of the recent global rise of 'authoritarian populism.' According to the Emancipatory Rural Politics Initiative's framing article (Scoones et al. 2018, 2-3),

Authoritarian populism ... typically depicts politics as a struggle between 'the people' and some combination of malevolent, racialised and/or unfairly advantaged 'Others', at home or abroad or both. It justifies interventions in the name of 'taking back control' in favour of 'the people', returning the nation to 'greatness' ... Authoritarian populism frequently circumvents, eviscerates or captures democratic institutions, even as it uses them to legitimate its dominance, centralise power and crush or severely limit dissent. Charismatic leaders, personality cults and nepotistic, familial or kleptocratic rule combined with impunity are common [...] features of authoritarian populism. 
On the other hand, many left-wing parties and governments (especially in Latin America) are both populist and authoritarian, and therefore fit in this broad definition. Hence, we need to acknowledge the substantial differences between left-wing and right-wing authoritarian populisms (Borras 2019) and that the recent global rise of authoritarian populism is mainly about the rise of the far-right (Gürel 2018). By implementing neoliberal policies, frequently defining its opponents as anti-national and anti-religious enemies, presenting its rule as a historically significant transfer of power from the elites to the people and thereby the end/reversal of (more than a century long) decline of the Muslim Turks, creating a personality cult around its leader, and dramatically weakening the checks and balances mechanisms, the AKP rule is clearly a part of the recent global ascent of the far-right.

A sizable portion of the literature has investigated the rural roots of historically important far-right movements in agrarian class conflicts. Robert Paxton (1997, 154-160; 1998, 13-14), for instance, contextualizes the success and failure of far-right movements within the background of massive farm worker strikes in Germany (1919-1923), Italy (1920-1921), and France (1936-1937). Both the state and fascist paramilitaries helped agrarian capital to crush the strikes. While the continuing effectiveness of state violence minimized the agrarian capital's need for paramilitaries and ruled out a fascist takeover in France, the weakness of the state in the Italian countryside increased the agrarian elites' reliance on fascists and helped Mussolini's swift triumph. In Germany, vigilantes supported by the local authorities broke the agricultural strikes. This agrarian reaction led to the rise of a variety of far-right organizations and later, the Nazis (Grill 1982, 152, 184). Similarly, Walden Bello (2018) shows that agrarian capital's goal of suppressing progressive lower-class mobilizations and the degree of reliance on the violence of state and paramilitary groups were key factors shaping the diverse trajectories of counterrevolutionary movements in Chile, Indonesia, and the Philippines in the second half of the twentieth century.

These insights help us to place the AKP's rural politics in the proper comparative-historical perspective. Although the use of violence is not absent in their history, Turkish Islamism generally used non-violent methods of taking power, which clearly distinguishes them from classical fascism. Also, although the AKP government has used coercive methods against its opponents since the beginning of its rule, these practices significantly differ from the cases of fascist agrarian reaction illustrated above. The AKP government has deployed coercive methods against its rightist and leftist opponents. The intensity of such coercive methods increased significantly after the Gezi protests of 2013, which marked the limits of the AKP's Islamist project in attaining its goal through mostly consensual methods. None of these opposition movements are rooted in agrarian class conflict. Moreover, there has not been any significant movement of farm workers or small farmers to force agrarian capital to seek the help of intensive state or paramilitary violence. Hence, increasing authoritarianism in contemporary Turkey cannot be explained by agrarian capital's reaction against the movements of agrarian classes of labor. ${ }^{6}$

On the other hand, we find the literature on the role of welfare provision in the rise of far-right movements very useful in explaining the AKP's persistent rural support. Hence, in

\footnotetext{
${ }^{6}$ On the other hand, although the urban labor movement has not been powerful enough to necessitate paramilitary violence, it has certainly been a factor behind increasing authoritarianism in Turkey. Between 2003 and 2018, the government banned 14 large-scale labor strikes that involved 192,000 workers. Nine of these strike bans took place after 2014 (Hak İnisiyatifi İstanbul 2018). In a speech given to Turkish investors in 2017, the president explained the strike bans:
} 
the Turkish context, class analysis is necessary not to explain the agrarian class conflict triggering a far-right reaction in the service of agrarian capital but to understand the circumstances in which a dramatic increase in welfare provision enables a far-right party to create a mass base of rural lower classes positioned against the mainstream parties. The global literature on far-right movements shows that although the intensive use of coercion against left-wing rural organizations before and after taking power has been a critical factor, it cannot in and of itself explain the success of the far-right in the countryside, as bidding for political power requires a sufficiently large mass base. In fact, far-right movements and regimes established rural hegemony by keeping some of their redistributive promises without significantly altering the existing class structure. In her comparative analysis of the rural support of fascism, Nazism, and Perónism, Leslie Anderson (2006) underscores the critical role of the partisan-style provision of welfare and other services. In Italy,

[Fascist] unions, working directly with landlords, delivered rewards and concessions quickly without having to produce changes in the laws, as socialists were working to do [...] Over time it became increasingly clear that it was financially beneficial to join fascism, but financially unrewarding and downright dangerous to remain a socialist. (2006, 199-200, emphasis added)

Similar factors played out in the German countryside in the late 1920s and 1930s:

The Nazis organized soup kitchens and other measures to bring immediate aid to rural folk. They offered credit support and small loans to confront the credit crisis and foreclosure threats. As with the Italian fascists, each of these benefits was restricted to Nazi supporters [...] After gaining national power, [...] material support included further credit support, price support, and a new law that disallowed foreclosures. (Anderson 2006, 202)

Finally, welfare-based partisanship underlined the rural hegemony of Perónist authoritarian populism in Argentina between 1946 and 1955:

To provinces that supported his movement, Perón delivered roads, schools, electricity, potable water, and public-works projects. The Eva Perón Foundation created a nationwide patronage system whereby provincial supporters could write to Eva for individual material aid such as sewing machine or medicine for a sick child. In the poverty of rural Argentina, such material and development efforts were the first time many rural dwellers had ever received anything from the government. $(2006,205)$

As in these historical cases, welfare provision continues to play a key role in winning villagers' support of reactionary politics. In fact, 'in rural settings, we see subsidy policies, social welfare support, and local economic development, alongside trade protection, sovereignty and anti-globalisation narratives, being promoted by right-wing, authoritarian regimes' (Scoones 2018).

We argue that a similar dynamic has underlined the AKP's hegemony in rural Turkey. AKP's success has been based on the combination of 'social neoliberalism' (Dorlach

We use the state of emergency for the business people's benefit. Let me ask: Do you encounter any trouble, any delays in the business world [now]? When we assumed power [in 2002], there was [also] a state of emergency in Turkey, but all the factories were facing the threat of strikes. Remember those days. But now, thanks to the state of emergency, we immediately intervene in those workplaces that face the threat of strikes. (Bozkurt-Güngen 2018, 232)

The state of emergency was declared on 20 June 2016, five days after the failed coup attempt, and continued for two more years. 
2015; Öniş 2012, 137) and increasing authoritarianism. Social neoliberalism occupies an intermediate position on the spectrum of orthodox neoliberalism on the right and social democracy on the left. It differs from social democracy since its 'social reforms are more uneven and remain coupled with more orthodox economic policies.' By recognizing that 'poverty and inequality require, at least in part, political solutions,' social neoliberalism distinguishes itself from orthodox neoliberalism (Dorlach 2015, 524). What motivates social neoliberalism's sensitivity to the question of poverty is its perception of the serious political risks associated with orthodox neoliberalism. Across the globe, the lower classes have rejected neoliberal policies through street protests, armed insurgencies, revolutions, and the ballot box. By providing a variety of material concessions to lowincome groups, a strategy often branded as 'controlled populism' (Güven 2016, 1007), social neoliberalism offers (at least) a temporary political fix to contain the radicalization potential of peasants and workers and to win elections (Dorlach 2015, 521; Öniş 2012, 137). ${ }^{7}$

We argue that the AKP has competently followed a line of social neoliberal policy since 2002. On the one hand, it has followed the orthodox neoliberal prescription by privatizing state-owned enterprises and increasing the precariousness of the labor market. On the other hand, as we show below, AKP has shifted away from the orthodox neoliberal prescription through limited increases of agricultural support and significant expansion of social assistance to the rural and urban poor. In addition, the dramatic expansion of credit, which increased the household debt to GDP ratio from 1.9 percent in 2002 to 22.6 percent in 2013, also helped the AKP to expand its popular base (Bozkurt-Güngen 2018, 228-229, 234). In sum, while the AKP's increasingly coercive methods narrowed the scope of labor empowerment through collective mobilization by workers' and farmers' unions, its social neoliberal policies helped the urban and rural laboring classes' "'disciplining by unmediated/individual incorporation" into the AKP's political project as consumers, credit users and social assistance recipients' (Bozkurt-Güngen 2018, 220). Despite the temporary economic slow-down of 2008-2009, the Turkish economy has not faced catastrophic crisis. GDP per capita (in current US\$) increased from $\$ 3,660$ in 2002 to $\$ 12.542$ in 2013 and then decreased to $\$ 10.540$ in 2017. GDP per capita (in constant 2010 US\$) rose from $\$ 8,003$ in 2002 to $\$ 14.933$ in 2017 (World Bank 2018). This has created enough financial space for the AKP government to follow a social neoliberal line, which has been immensely helpful for its hegemony. ${ }^{8}$

\section{Agricultural policies before the AKP}

The foundation of the AKP on 14 August 2001 was a result of the split within the National Vision Movement (Milli Görüş Hareketi), the brand name for the tradition of legal Islamist parties in Turkey (a tradition dating back to the early 1970s). The Welfare Party (Refah Partisi, RP) represented this political line in the 1990s. Turkish Islamism achieved its first significant successes under the RP in the mid-1990s. The RP won the İstanbul and

\footnotetext{
${ }^{7}$ On the question of the use of welfare provision as an apparatus of political containment and mobilization of the poor, also see Yörük 2012.

${ }^{8}$ As the Turkish economy currently enters into its severest downturn since 2001, the AKP will certainly face a formidable challenge to pursue social neoliberalism as before. We briefly discuss this in the last section, but a detailed discussion of the prospects of the AKP and its opponents in the light of the ongoing economic crisis is beyond the scope of this paper.
} 
Ankara metropolitan municipality elections on 27 March 1994. It received 21.38 percent of the popular vote and won the general elections on 24 December 1995. A large portion of the founders of the AKP held important positions in the RP such as top party officials, ministers, deputies, and mayors. Tayyip Erdoğan was the mayor of the İstanbul metropolitan municipality between 1994 and 1998.

Six months after the 1995 election, the RP formed a coalition government with the center-right True Path Party (Doğru Yol Partisi, DYP). The RP-DYP coalition remained in power between June 1996 and June 1997. Agricultural producer support (as percent of gross farm receipts) increased from 25.5 percent in 1996 to 31.6 percent in 1997 (OECD 2018a). Hence, small farmers did not have much reason to criticize the RP. On 28 February 1997, Turkish military command used the threat of a coup to force the RP-DYP government to accept a series of secular reforms aiming to prevent the further rise of Islamism. Following that intervention, the alliance of the military command, the secular bourgeoisie (including those controlling the majority of the mass media), and the leaders of major labor unions put heavy pressure on the government, which brought it to collapse six months later. Both the rural and urban poor viewed it as a grave injustice to a government composed of devout people working for their interests. The popularity of Tayyip Erdoğan who was imprisoned for four months in 1998 after reading an Islamic poem during an RP demonstration, stripped from his post as the mayor of İstanbul, and banned from the parliamentary elections of 2002- rapidly increased.

Later developments consolidated the masses' positive outlook on Islamists. The coalition government of the center-left Democratic Left Party (Demokratik Sol Parti, DSP), the ultranationalist Nationalist Action Party (Milliyetçi Hareket Partisi, MHP), and the center-right Motherland Party (Anavatan Partisi, ANAP) remained in power between May 1999 and November 2002. Two of the three severest economic crises of the post1980 period (1994, 1999, and 2001) occurred during the rule of the DSP-MHP-ANAP coalition. Compared to 1998, the GDP per capita contracted by one-quarter in 2002 (World Bank 2018). The crises of 1999 and 2001 forced the government to draw loans from the IMF, which were conditional on the implementation of a neoliberal policy package, including drastic cuts to the agricultural support expenditures. World Bank Vice President, Kemal Derviş, was launched into the seat of the Minister of Economic Affairs in March 2001, with a mission to guarantee strict implementation of the neoliberal reforms. Derviş quickly became the symbol of neoliberal orthodoxy and foreign economic influence. Agricultural support (as percent of gross farm receipts) decreased from 36.4 percent in 1999 to 32.3 percent in 2000, and 16.8 percent in 2001. Its increase to 26 percent in 2002 (OECD 2018a), did not meaningfully alleviate the damage done to small farmers. The Tobacco Law of 2001 eliminated state procurement of tobacco and resulted in the decline of tobacco-producing households from 583,400 in 2000 to 401,200 in 2002. The Sugar Law of 2001 implemented similar measures (Aydın 2010, 163-172). In 2002, the DSP-MHP-ANAP coalition eliminated previous forms of government support to agriculture and adopted a direct income support policy that provided cash assistance to farmers cultivating less than 50 hectares. Direct income support was provided to everyone documenting farmland ownership, regardless of whether they actually cultivated or not. In other words, it cut the historically close link between government support and agricultural production. Its primary aim was to contain the risks stemming from the neoliberal assault on small farmers and their resulting rapid proletarianization (Gürel 2014, 348-350). 
The neoliberal assault against small farmers and workers made the DSP-MHP-ANAP government very unpopular. Many worker and farmer protests took place in 2001 and 2002 (Gürel 2014, 370-371). Although mainstream media did not side with the protestors, media coverage of mass disappointment and protests was much broader than today and negatively impacted public opinion of government policies. As a result, the coalition crumbled, and an early election was scheduled for 3 November 2002. The combined vote shares of the coalition parties declined from 53.4 percent in 1999 to 14.7 percent in 2002 (Turkish Statistical Institute 2012). One of the notable features of the election campaign in 2002 was the inclusion of Kemal Derviş in the list of deputy candidates of the center-left CHP, which revealed the party's neoliberal orientation once more. More importantly, it also demonstrated the CHP's utter incompetence with regard to understanding the mood of the lower classes at that time. Erdoğan's AKP, established only a year earlier, received 34.3 percent of the popular vote, followed by the CHP, which received only 19.4 percent of the popular vote (Turkish Statistical Institute 2012). The AKP controlled the parliamentary majority and formed a government on 19 November 2002.

\section{The AKP's social neoliberalism in rural Turkey}

The AKP government has not changed the neoliberal course of agricultural policy. The transition of Turkish agriculture from a smallholder-based to an agribusiness-based structure has continued unabated. Employment of wage labor and contract farming become increasingly prevalent relations of agricultural production. On the other hand, the government has introduced a series of policies that have helped to make the neoliberalization process relatively acceptable among small farmers and proletarianizing villagers. Since the AKP inherited a very low support base (in terms of agricultural support, economic growth performance, and political popularity) from the previous government, these policies have helped the party to broaden its rural support base.

The AKP government brought back producer support for crop production and animal husbandry in 2004 (Güven 2009). Rather than simply returning to older policy, the party has since liberalized the support policy (Keyder and Yenal 2013,60). Agricultural regions of Turkey were divided into basins, listing the (suggested) competitive advantage of each basin's products and distributing subsidies and other forms of financial support accordingly. An increasing portion of agricultural support has since been given to the production of certified organic products. The basin-based support policy favors the mediumand large-scale producers over smaller ones (Gürel 2014; Oral 2010; Yıldırım 2017a). Nevertheless, the total amount of agricultural support has increased. The level of agricultural support in Turkey was significantly below the OECD average in 2001 and 2002, and has been consistently above it since 2003 (OECD 2018a). ${ }^{9}$ The ratio of irrigated area to total agricultural area did not decline (12.6 percent in 2002 and 13.5 percent in 2014). Although Turkey's agricultural dependency has increased (the value of imports of agricultural and animal products in 2017 is 5.6 times that of 2002, whereas the volume of exports in 2017 is 3 times that of 2002), major indicators of agricultural production have not declined (Turkish Statistical Institute 2018). The index $(2004-2006=100)$ of crop production

${ }^{9}$ On 20 February 2018, the government announced that it would cover half of the gasoline expenditure of farmers (Sabah February 20, 2018). 
increased from 94.2 in 2003 to 119.3 in 2016, that of livestock production increased from 83.7 to 163.7 , and of that of food production increased from 93.7 to 134.4 within the same period (World Bank 2018). ${ }^{10}$ The average annual growth rate of agricultural value added was 1.3 percent between 1969 and 2002 and 2.6 percent between 2003 and 2016. The average annual growth rate of value added per worker in agriculture was 4 percent between 1991 and 2002 and 4.9 percent between 2003 and 2016. ${ }^{11}$ In sum, although the growth performance of Turkish agriculture has not been remarkable, the available evidence does not support the popular claim of a sharp agrarian crisis in the AKP era.

The AKP government has also implemented a series of social policy reforms to consolidate and expand its support base among the poor. Here, we define 'poor' broadly, including the unemployed population, low-income farmers, and full-time and part-time workers in low-wage jobs. The AKP's social policy programs include means-tested provisions of incash and in-kind assistance specifically targeting those below the official poverty rate. However, assistance is often given to those who do not fall below the poverty line. In fact, similar to other countries such as China (Chen, Pan, and Xu 2016) and Mexico (Ramírez 2017), the caseworkers of the Ministry of Family and Social Security in Turkey maintain a significant degree of discretion of defining who is poor and who needs assistance. Many people receive assistance despite being above the official poverty rate (Aytaç 2014, 1218-1219). Similar to the use of social assistance to contain political radicalization in other countries, the AKP government has used social assistance in order to contain the Kurdish movement (Yörük 2012). Public officials explicitly stated that they might consider freezing social assistance to families whose members participate in street demonstrations supporting the Kurdish movement (Milliyet October 30, 2008). More often, social assistance has been used to increase the AKP's support base among the poor to win elections.

The share of social expenditure in Turkey's GDP increased from 7.7 percent in 2000 to 10.3 percent in 2005 and 13.5 percent in 2014 (OECD 2018b). ${ }^{12}$ The ratio of households receiving public social assistance ('all in-kind and in-cash transfers from the general government budget to poor households, except for retirement pensions and tax repayments') doubled within just a decade, from 15.8 percent in 2002-2003 to 30.7 percent in 20102011. The same figure more than doubled in the countryside in the same period: from 31 percent to 67.8 percent for the 'landed subsistence peasants,' from 13.9 percent to 55.6 percent for 'landless subsistence peasants,' from 18.2 percent to 41.5 percent for 'agricultural laborers', and from 25 percent to 64.5 percent for the 'rural unemployed.' Moreover, the combined ratio of public and private social assistance in household income rose from 15.5 percent to 16.4 percent for landed subsistence peasants, from 7.2 percent to 18.8 percent for landless subsistence peasants, from 3.9 percent to 9.4 percent for agricultural workers, and from 51.2 percent to 61.4 percent for the rural unemployed (Bahçe and Köse 2017, 588). ${ }^{13}$

While the level of income inequality has not changed and wealth inequality has increased (Torul and Öztunalı 2018), the social assistance boom has reduced absolute

\footnotetext{
${ }^{10}$ Livestock has been the most problem-ridden sector during the AKP era. The number of cattle and volume of red meat production were stagnant until the early 2010s. However, they have since steadily increased. The production of other major livestock products (chicken meat, egg, milk, and honey) has increased in the entire AKP period (Turkish Statistical Institute 2018).

${ }^{11}$ Authors' calculations based on World Bank 2018.

${ }^{12}$ This is significantly below the OECD average of 21 percent (OECD 2018b).

${ }^{13}$ For specific definitions of these rural groups see Bahçe and Köse 2017, 592-595.
} 
Table 2. The AKP's vote share (\%) in Ordu.

\begin{tabular}{|c|c|c|c|c|c|c|c|}
\hline \multicolumn{2}{|l|}{ General elections } & \multicolumn{2}{|c|}{ Local elections } & \multicolumn{2}{|c|}{$\begin{array}{l}\text { Constitutional } \\
\text { referendums }\end{array}$} & \multicolumn{2}{|c|}{$\begin{array}{l}\text { Presidential } \\
\text { elections }\end{array}$} \\
\hline 2002 & 41.5 & 2004 & 40.2 & 2010 & 63.47 & 2014 & 66.98 \\
\hline 2007 & 55.8 & 2009 & 42.5 & 2017 & 61.88 & 2018 & 65.13 \\
\hline 2011 & 60.2 & 2014 & 52.6 & & & & \\
\hline June 2015 & 53 & & & & & & \\
\hline November 2015 & 63.1 & & & & & & \\
\hline June 2018 & 48.7 & & & & & & \\
\hline
\end{tabular}

Sources: Hürriyet 2018; www.secim.haberler.com; www.secim-sonuclari.com; Turkish Statistical Institute 2012.

(rural and urban) poverty in Turkey over the last 16 years (World Bank 2018). In other words, although the main beneficiary of the AKP's economic policy is the Turkish bourgeoisie (especially its Islamist wing), its social policy has made limited improvements to the living standards of low-income groups. This has contributed to the AKP's hegemony in poor neighborhoods and villages.

\section{The AKP's hegemony over hazelnut producers}

In 2015, Turkey produced about two-thirds of the world's total hazelnut export (Turkish Statistical Institute 2016). Rural areas surrounding the city of Ordu (located in the eastern Black Sea region) supply one-third of Turkey's hazelnut production (T.C. Gümrük ve Ticaret Bakanlığı Kooperatifçilik Genel Müdürlüğü 2017). Small and medium-sized farms dominate hazelnut production. Because opposition parties, journalists, and scholars have continuously claimed that government policies harm hazelnut production and small producers' interests (CHP 2016; İnce 2012), the AKP's consistently strong electoral performance in Ordu is a puzzle deserving of careful attention (Table 2).

Class struggle in the hazelnut sector occurs on two main levels. The first level includes the struggle of farmers and capital over the market price. Farmers demand prices significantly higher than those traders/exporters/corporations prefer to give. The Union of Hazelnut Sales Cooperatives (Fındık Tarım Satış Kooperatifleri Birliği, often called Fiskobirlik), founded in 1935, is a quasi-public entity. On the one hand, it represents all hazelnut producers and collects membership fees from them. On the other hand, it has acted as a government institution in regulating the hazelnut market. From the mid-1960s to the mid2000s, Fiskobirlik purchased hazelnuts from its member cooperatives on behalf of the government treasury at pre-determined prices. Fiskobirlik has also processed hazelnuts in its factories and marketed them in national and international markets (Fiskobirlik 2017). On the other hand, private capital -of both Turkish and foreign agribusinesses- has been an important player in the hazelnut sector. Fiskobirlik and government agencies have taken agribusiness interests into account when setting purchase prices. However, due to the significant bargaining power of farmers, capitalist interests have not unilaterally determined hazelnut prices. Historically, political concerns have been important in price determinations. During the 1960s and 1970s (the height of social movements and influence of the radical left), hazelnut producers organized many meetings and demonstrations. As in the rest of the country, the radical left was harshly suppressed in the region after the coup of 1980 . 
On the second level of class conflict, farmers' interests clash with those of farm workers. Although the average farm size is small, the picking of hazelnuts during summer months often requires outside labor. The great majority of farm workers come from the Kurdishmajority region of southeastern Turkey, especially since the forced migration policy of the 1990s, which quickly displaced and urbanized the Kurdish peasants (Yörük 2012). The wages of Kurdish farm workers are very low, and they lack decent working conditions, as well as social protection. As a result of the long history and increasing intensity of the Kurdish question, class antagonism between Turkish farmers and Kurdish proletarians involves an important ethnic dimension. ${ }^{14}$ Given the significant weakening of the radical left - the only force, which could act against chauvinism among the Turkish farmers- the ethnic dimension of agrarian labor relations has continuously swayed the politics of Turkish farmers in a right-wing nationalist direction. During our fieldwork in Ordu in 2018, farmers told us that they support the government's nationalist stance.

As in other parts of the Turkish countryside, economic crises and the neoliberal assault between 1999 and 2001 paved the way for the AKP's first election victory in Ordu in 2002. Nevertheless, soon after the election, farmers began to believe that the government was favoring the interests of the hazelnut exporters. The strong influence of Cüneyd Zapsu (the owner of Balsu Gıda, a hazelnut exporting company) on the AKP leadership became the personal target of farmers' criticisms (Cumhuriyet June 26, 2003). Major opposition parties openly blamed the government for the betrayal of hazelnut producers (Cumhuriyet August 3 \& 22, 2003). More importantly, the AKP did not have control over top management of Fiskobirlik at that time. Fiskobirlik executives openly criticized the government for the low prices and held meetings with the representatives of opposition parties (Cumhuriyet August 15 \& 24, 2003). Fiskobirlik also struggled with serious financial difficulties at the time. Its management requested government assistance for its credit applications to public and private banks, but the government refused. As a result, Fiskobirlik frequently delayed its payments to farmers for past purchases. The public perceived this as the AKP's punishment of Fiskobirlik for its refusal to side with it (Ekşi 2006; Karpat 2006). In the early 2000s, criticisms of the AKP's policies (both inside and outside the party) were much more explicit than it is today. Several AKP officials heavily criticized the hazelnut policy in 2003 (Cumhuriyet August $3 \& 9$ \& 15 \& 16, 2003).

Mass dissatisfaction regarding hazelnut prices continued over the next few years, finally culminating in 2006, the first year that the AKP government left the power of price setting entirely to the authority of hazelnut exporters. For the first time in the history of the Turkish republic, hazelnut harvest season began without the government's declaration of a minimum procurement price (Cumhuriyet August 11, 2006), which slashed the market price almost in half. Ordinary farmers, Fiskobirlik, The Chamber of Agriculture (Ziraat Odası), The Farmers' Union (Çiftçi-Sen), and opposition parties opposed the move (Cumhuriyet July 29 \& August 30, 2006). Growing farmer dissatisfaction led to a series of protests. Things finally erupted on July 31 . About 100,000 hazelnut producers coming from different parts of the eastern Black Sea region gathered for a protest meeting in Ordu. After the meeting, protestors blocked the Ordu-Samsun highway for about eight hours before being dispersed by the gendarmerie and police forces. Many protestors and security

\footnotetext{
${ }^{14}$ For detailed fieldwork-based analyses of the relationship between Turkish farmers and Kurdish farm workers in different regions of Turkey, see Duruiz 2015; Pelek 2010.
} 
forces were wounded (Hürriyet July 31, 2006). This is one of the largest farmer protests in modern Turkish history. Small-scale farmer protests (also involving the members of the local branches of the AKP) continued in Ordu in the following months (Cumhuriyet September $7 \&$ 10, 20-22, 2006, April 5 \& 8, 2007).

Although the great majority of protesting farmers did not sway towards the radical left, the radical left's organizational efforts in the region should not be overlooked. The Union of Hazelnut Producers (Fındık Üreticileri Sendikası, Fındık-Sen), founded in 2004, played a significant part in organizing small farmers and participating in farmer protests (FındıkSen 2017). Some socialist organizations such as the Freedom and Solidarity Party (Özgürlük ve Dayanışma Partisi, ÖDP), the People's Houses (Halkevleri), the Socialist Democracy Party (Socialist Democracy Party, SDP), and the Communist Party of Turkey (Türkiye Komünist Partisi, TKP) have also worked in the region. The ÖDP organized a march of hazelnut producers from Trabzon to Ankara in the summer of 2006 (Cumhuriyet July 25 \& October 1, 2006). However, such efforts have not been effective for three main reasons. First, the politics of the radical left in Turkey has not yet recovered from the twin shocks of the military coup of 1980 and the collapse of the Eastern Bloc in 1989-1991. Second, above-mentioned ethnic division of farm labor shifted the politics further towards the nationalist right. Finally, the AKP government has been very careful in containing the radical left by all means possible. More than a decade after its foundation, Fındık-Sen's legal status as a union has still not been completely recognized. Leftist activists are under significant pressure. For example, despite their lack of political influence, socialist activists were the primary targets of police arrests following the July 31 protest (Cumhuriyet August 18, 2006). ${ }^{15}$

Farmer protests were alarming signals for the AKP before the general election on 22 July 2007. Political polarization between Islamists and secularists increased before the election. Abdullah Gül, the then second most important figure of the AKP, was chosen to be the presidential candidate of the party. The AKP claimed enough seats in the parliament to elect him. However, secular opposition (represented by the CHP in the parliament and numerous minor Kemalist groups outside the parliament) campaigned against Gül's presidency, which led the constitutional court to freeze the election process. On 27 April 2007, the military's top command issued an online statement blaming the government for the erosion of secularist foundations of the Turkish state. Hence, the July 2007 election became a political battle of decisive importance. The AKP had to win the election, ideally by increasing its vote share, in order to cut the Gordian knot.

The AKP swayed towards a more populist-leaning hazelnut policy in 2007. During the first half of 2007, the government paid all its debts to farmers (for crop procurement and compensation of the losses caused by natural calamities such as drought and frost). Moreover, these 2007 payments were made in advance (Cumhuriyet April 9, 2007). More importantly, on July 9, less than two weeks before the election, the government announced a 28.7 percent increase in the minimum price. Both the Fiskobirlik management and the local branches of the Board of Agriculture praised this decision (Cumhuriyet July 10, 2007). Finally, small farmers and proletarianized villagers viewed the AKP's social policy

\footnotetext{
${ }^{15}$ The weakness of the center-left CHP is another factor behind the AKP's regional power. As a hazelnut producer in the Ulubey district of Ordu told us, 'The people can't benefit from the other side [center-left]. There was Ecevit before, but now there is no one.' Bülent Ecevit was the most popular leader of the center-left in the 1970s. He was the prime minister of the DSP-MHP-ANAP government between 1999 and 2002. Ecevit died in 2006.
} 
positively (Cumhuriyet July 24, 2007). As a result, the AKP won 55.8 percent of the votes in July 2007.

After the electoral victory of 2007, Fiskobirlik management did not have much choice but to surrender to the AKP. In turn, the AKP swiftly took control of the organization (YIldırım 2007). Given the historical importance of Fiskobirlik in the hazelnut sector, its control by the AKP represented a decisive victory and helped the party to further its hegemony in the region. Over the years, the government has since transformed Fiskobirlik into a branch of the Soil Products Office (Toprak Mahsulleri Ofisi, TMO), which has allowed for more direct government control over the hazelnut sector. In our fieldwork in Ordu, we observed that farmers no longer mention Fiskobirlik. They only refer to the TMO when discussing the government's procurement policy. The farmers stated that the AKP government is not responsible for the decline of Fiskobirlik. According to one interviewee,

The liquidation of Fiskobirlik has nothing to do with the AK Party government. Fiskobirlik went bankruptcy. The state can't sustain it. People want jobs from the state, but it cannot do this.

Even if the AK Party government goes, the state will not establish factories.

This discourse is strikingly similar to the post-1980s pro-privatization discourse of blaming public enterprises for inefficiency and corruption.

Important changes have taken place in the hazelnut market in recent years. After buying Oltan Gıda (a Turkish trading company) in 2014, Ferrero (an Italian agribusiness) achieved market dominance. Like Ferrero, the Singaporean Olam Gida became a major player after purchasing Progıda (a Turkish trading company) in 2011. Cüneyd Zapsu's Balsu Gıda is the third largest player in the hazelnut market (Dünya November 20, 2011; Yıldırım 2017c). Greater market dominance of these companies has decreased the state's capacity to influence hazelnut prices, but the AKP has continued using pricing to win elections. Just before the critical constitutional referendum of April 2017, for instance, the government announced that the TMO was going to purchase a significant quantity of hazelnuts from farmers in order to prevent its price from falling below 10 Turkish liras per kilogram (Yazan 2018; Yıldırım 2017b). As one farmer in Ordu told us, 'They are giving the subsidies in such critical periods, right before the elections or in March when all the producers go broke ... They throw something at the people and the people jump on it.'

\section{AKP's hegemony over tea producers}

Attempts at expanding tea production around the city of Rize in the eastern Black Sea region date back to the late nineteenth century. Since then, the volumes of tea produced have increased gradually, and Turkey has become the world's sixth largest exporter of processed tea in 2016. Rize is currently the most prominent tea-producing city with 131,443 tea producers supplying 61.8 percent of all national production (ÇAYKUR 2016). Until 1984, there was a state monopoly in the tea sector. The state controlled the tea sector through TEKEL until 1971, when the General Directorate of Tea Enterprises (Çay Kurumu, ÇAYKUR) was founded as the only state-owned monopoly enterprise. In 1984, the restriction on the private investment in the sector was removed along with other liberalization reforms. The private sector started to invest in the procurement, packaging, and distribution of tea. However, despite the increasing private investments in the tea sector by national and transnational corporations, ÇAYKUR is still the most powerful actor in the procurement 
Table 3. AKP's vote share (\%) in Rize.

\begin{tabular}{|c|c|c|c|c|c|c|c|}
\hline \multicolumn{2}{|l|}{ General elections } & \multicolumn{2}{|c|}{ Local elections } & \multicolumn{2}{|c|}{$\begin{array}{l}\text { Constitutional } \\
\text { referendums }\end{array}$} & \multicolumn{2}{|c|}{$\begin{array}{c}\text { Presidential } \\
\text { elections }\end{array}$} \\
\hline 2002 & 44 & 2004 & 46.4 & 2010 & 76.04 & 2014 & 80.57 \\
\hline 2007 & 53.66 & 2009 & 46.80 & 2017 & 75.06 & 2018 & 76.92 \\
\hline 2011 & 69.06 & 2014 & 67.9 & & & & \\
\hline June 2015 & 66.76 & & & & & & \\
\hline November 2015 & 75.88 & & & & & & \\
\hline June 2018 & 64.85 & & & & & & \\
\hline
\end{tabular}

Sources: CNN Türk 2018; www.secim.haberler.com; www.secim-sonuclari.com; Turkish Statistical Institute 2012.

and distribution of tea. In 2016, ÇAYKUR purchased 53.1 percent of all tea produced. Despite the long debates over its privatization, ÇAYKUR has been excluded from the privatization program. In 2017, it was transferred to the newly created Turkey Wealth Fund (ÇAYKUR 2018).

As Table 3 demonstrates, the AKP has been dominant in Rize since 2002. The continuation of subsidization is an important factor behind this success. Purchases by the ÇAYKUR did not decrease and subsidy payments continued (T.C. Gıda, Tarım ve Hayvancılık Bakanlığı 2017). In addition to existing support mechanisms, the government has recently started to encourage producers to shift to organic tea production.

Our fieldwork in Rize in 2018 revealed that delayed payments, favoritisms in quota arrangements and corruption in ÇAYKUR in previous periods were major problems for producers. Almost all interviewees expressed their satisfaction with the current management of ÇAYKUR. One of them said,

Now, there is an appointment-based system. No nepotism. The state still does not purchase all the tea we produce. But the volume that will be purchased is pre-determined at the beginning of the season. The AK Party brought this system.

Another producer stated,

In the 1990s, ÇAYKUR was out of cash and not able to purchase tea from us. But today, it is. This government came to power and gave the money. Tea prices decreased, but at least we can see our future today.

Especially the memory of the 2001 crisis is still very alive among the producers, when they talk about the developments in the AKP period. A producer from the lyidere district stated,

The 2001 crisis affected us adversely. ÇAYKUR had gone to pot. When Erdoğan came to power, he put ÇAYKUR in order. Both the workers and the tea producers did not trust ÇAYKUR. Now, a producer gets his money ten days after he delivers his tea.

In 2009, the AKP government drafted a neoliberal law aiming to weaken ÇAYKUR, increase the power of private agribusiness companies in tea production and trade, and hasten the transformation of small tea producers into contract farmers. In response to small producers' strong opposition, the government did not push for the legislation of the draft law (Genç 2016, 271-279). In short, similar to the case of Ordu, the Rize case shows the importance of AKP's bargaining with villagers in its persistent rural support.

Construction and infrastructural investments in the region have also increased significantly. New highways, airports, bridges, housing estates, schools, hospitals, and mosques have been constructed. Although the AKP has not solved the unemployment problem, the 
rise of construction and infrastructural investment has increased the employment prospects for the lower classes and provided a (limited) opportunity for upward mobility. ${ }^{16}$ This is also the case in Rize. One of our interviewees stated, 'I had an old junky car 15 years ago. Now, I have six cars today. I am working in construction in addition to producing tea. The construction sector has developed in Rize.' As lands are fragmented into smaller pieces, producers diversify their income by seeking jobs in the service sector, opening coffee houses, barber shops, grocery shops, etc. Almost all households have at least one retired person who contributes to the household income. Improvements in the welfare system and social assistance are also effective mechanisms behind the high popular support for the AKP government. One of the tea producers stated, 'Today, there is no difference between the public and private schools.'

The expansion of social assistance, in addition to welfare investments, has become effective in encouraging producers' support for the AKP government. In addition to the effective use of social assistance and welfare mechanisms among the producers, the responsibility for poverty is associated with the lack of individual effort rather than the problem of the government policies. In other words, producers who support the AKP government perceive poverty as an individual problem caused by the individuals themselves in a context where social assistance and welfare mechanisms are sufficiently advanced. A tea producer stated, 'They are helping the elderly. They are giving coal to the needy ... There is no one poor in Rize. People who know how to do things, people who work are not poor.'

\section{Rural politics in the context of construction, mining, and energy booms}

The construction, mining, and energy sectors have been important engines of economic growth and symbols of rule during the AKP period (Adaman et al. 2018; Arsel, Akbulut, and Adaman 2015). In the Black Sea region, constructions of fossil fuel and hydroelectricity plants have generated popular resistance in rural areas such as Gerze (Sinop), Cerattepe (Artvin), Fındıklı (Rize), Hemşin (Rize), Fatsa (Ordu), and Cide (Kastamonu). However, these resistances have not led to a significant change in their residents' political dispositions. In April 2018, just two months before the snap elections, district organizations of four major parties (including the government party AKP's district organization) and 12 village headmen made a joint declaration demanding the suspension of the construction of hydro-electricity plants in Hemşin (Evrensel April 9, 2018). Despite this seemingly wide consensus against hydropower plants, Erdoğan took 65.9 percent of the popular vote in Hemşin in June 2018 (Sabah June 24, 2018). The case of Gerze is similar. AKP received 44.5 percent of the popular vote in the 2007 elections. Protests by villagers and urban activists against the construction of a coal power plant in Gerze began in 2008 and peaked in 2011 (Arsel, Akbulut, and Adaman 2015, 4). This did not change the political landscape, however. AKP received 48.5 percent of the vote in 2011, 44.5

\footnotetext{
${ }^{16}$ Walden Bello $(2018,43)$ identifies a similar process in Thailand in the $2000 \mathrm{~s}$ :
}

The complex character of Thaksin's rural mass base stemmed from the fact that the spread of capitalist production relations and the commercialization of land had contradictory effects, impoverishing some while providing an opportunity for others, including people who were able to access the pro-Thaksin government support to help them build small businesses. Both losers and winners appeared to come together in support of Thaksin. 
percent in June 2015, 53.4 percent in November 2015, and 53.7 percent in 2018 (http:// www.secim-sonuclari.com).

The incompatibility between environmental protests and political preferences ${ }^{17}$ is partly related to the fact that the outcomes of environmental and resource policies usually become visible in the long run and therefore do not immediately affect political dispositions (Adaman and Arsel 2010, 329). Increasing land prices due to construction and extraction boom also affect people's perceptions. The construction of the OrduGiresun and Rize-Artvin airports triggered land price increases in the region, which in turn encouraged locals to sell their farms (Hürriyet July 5, 2015). Local people positively view land price increases. One interviewee from the lyidere district of Rize stated: 'Now we have constructions [...] constructions of hospitals, roads and hydropower plants. People are selling their lands. They pay well. I also sold my land for a high price.' Similarly, villagers' (partially realized) expectations of high compensation for their land acquisitioned by the state weakened the resistance against the construction of the Yusufeli Dam in Artvin (Evren 2016, 282).

The individual interest in rent increase resonates with the narrative of national development, which is deeply rooted in the imagery of the Turkish state. The AKP government has presented the construction and extraction boom as a manifestation of successful economic development (Arsel, Akbulut, and Adaman 2015). In some cases, protest movements against hydropower plants caused local populations to react. Local people staged demonstrations showing their support to hydropower projects in the Kalkandere district of Rize city in 2009 (Pazar53 May 22, 2009) and Cide district of Kastamonu city in 2010 (Haberler.com December 21, 2010). The anti-hydropower activists were blamed for posing a threat to economic development. During our fieldwork in Rize and Ordu, we also observed the prevalence of this developmentalist narrative among the AKP supporters. One of our interviewees expressed his support of hydropower plants by saying, 'we are producing our own energy and reducing our foreign dependency.' Interestingly, national identity of the actors also shapes the distributive expectations of the villagers. For instance, following the retreat of the two international consortiums due to local resistance, Turkish state became the main investor of the Yusufeli Dam project. Local people then stopped resistance and started to bargain with state officials over compensation (Evren 2016, 270). Regional identities also matter. For example, the involvement of businessmen from Trabzon is seen as a reason of the weakness of resistance against hydropower plants in Trabzon located in the Eastern Black Sea region (Hamsici 2011, 83).

Finally, the consent-making mechanisms discussed throughout this paper are also at play in hydropower projects. Job creation through power plants and companies' investments in local infrastructure (such as repairing village mosques) resulted in such consent in Rize and Kastamonu. Sometimes, companies contact villagers' city-dwelling relatives to garner approval for their projects. One company, for example, donated money to the village compatriot association located in Istanbul in order to gain the villagers' approval of a hydropower project in a village of Kastamonu. Finally, government investment also facilitates the completion of new projects. The case of Düzce, a city in the Western Black Sea region, is instructive in this regard. The Marmara Earthquake of

\footnotetext{
${ }^{17}$ Based on the International Social Survey Program's 2010 survey data, Ali Çarkoğlu $(2017,172)$ concludes that environmental issues have 'little electoral importance' in Turkey. Our analysis confirms this conclusion.
} 
1999 damaged the local economy. Local villagers believe that the AKP government's economic investments allowed the region to recover more rapidly and therefore do not resist the hydropower projects. ${ }^{18}$

\section{Results and prospects}

Four main conclusions can be drawn from our study. First, since the center-left and centerright parties lost much of their credibility during the 1990s, and because two severe economic crises and a harsh neoliberal assault took place during the DSP-MHP-ANAP coalition period (1999-2002), a large proportion of small farmers and proletarianized villagers do not directly associate the AKP with the unpopular neoliberal policies. Second, as the cases of Ordu and Rize reveal, the rural masses have not been entirely silent since 2002. They have used both protests and the ballot box as mechanisms of negotiation with the government. Third, although the AKP has not shifted away from neoliberalism, it has selectively used the agricultural support mechanism to maintain its support base among small farmers. More importantly, by expanding the coverage and quantity of social assistance, the AKP has sustained its support among the poor and proletarianized villagers. Along with continuous economic growth and rapid infrastructural development, these practices have helped the AKP to maintain a relatively positive perception among the rural masses. Finally, the AKP government has continuously used coercive measures to prevent the emergence of emancipatory alternatives.

Although this study paints a generally bleak picture regarding rural politics in contemporary Turkey, the intention is not to disseminate pessimism. This paper shows that the rural masses have not been entirely passive and have managed to win tangible material concessions from the AKP. Nevertheless, it is also clear that the great majority of rural protestors have continuously supported the AKP, and the left has remained weak and marginal. As the world is currently witnessing the rise of far-right politics of various sorts, there is no magic formula to solve this political problem in Turkey, but there are some key arguments to be made for the discussion and practice of a new emancipatory rural politics. First, the left should stop reading agrarian change during the AKP period as a simple process of de-agrarianization and impoverishment. As we have seen, the process has been much more complex. Also, Turkey has not witnessed an economic crisis comparable to those in 1999 and 2001. Finally, rural masses have received a significant degree of material concessions from the AKP. In short, people are not acting entirely irrationally.

On the other hand, the dynamics discussed in this paper may change in the near future. The Turkish economy is currently entering its worst crisis during the AKP era (and maybe one of the worst crises in the history of the republic) (Akçay and Güngen 2018). Maintaining the current levels of agricultural subsidies, social assistance, job creation, and creditdriven household consumption, let alone their expansion, will be extremely difficult for the government. In other words, AKP's social neoliberalism is bound to face significant constraints in the near future. On the other hand, it should be noted that the last crisis brought the AKP to power, and there is absolutely no reason to expect that the current

\footnotetext{
${ }^{18}$ Information given in this paragraph is based on e-mail communications with Ayşe Nal Akçay (September 25\&26 2018), who has conducted her dissertation research on resistance to hydropower plants in Turkey. For similar observations, see Hamsici 2011, 19-20.
} 
crisis would empower a progressive alternative. Although increasing authoritarianism has narrowed down the scope for political dissent, the left cannot avoid its responsibility of building a united pro-labor political alternative in the context of the current crisis. This includes organizing campaigns in order to give voice to economic problems of the laboring classes and to demand greater agricultural support expenditure, the creation of new jobs, and stronger social protection. Short-term campaigns waged by a small handful of organizations will not work. Instead, a large-scale and united effort is needed in order to place economic problems and demands at the forefront of politics - the only potentially effective act that might break authoritarian right-wing hegemony over the lower classes.

Given the fact that former Kurdish peasants who were displaced in the early 1990s currently comprise the great majority of seasonal farm workers and a sizeable minority of the urban workers in Turkey, they are critical actors for any class-based rural alternative. However, neither the Kurdish movement nor the socialist movement has achieved any significant progress in organizing seasonal farm workers. Although the recent narrowing down of political space for open dissent is certainly an important factor, pinning this failure on state repression alone would be an unconvincing explanation, as the situation was not significantly better before the AKP rule. Overall, there is no shortcut to overcome the current political impasse without the existence of a broad anti-capitalist coalition requiring strict organization and close monitoring of day-to-day class-based politics.

As shown above, the dramatic expansion of social assistance has helped the AKP's hegemony over large sections of the laboring classes. The government controls enormous economic resources, and at least in the realm of social assistance, no political force can compete with it. Hence, progressive forces should not engage with such competition because they cannot win. They should, however, take this issue very seriously and establish strong mechanisms of material and economic solidarity as a backbone for their united political efforts. ${ }^{19}$

\section{Acknowledgements}

We would like to thank the Emancipatory Rural Politics Initiative (ERPI) for the small grant that facilitated our research and KONDA Research and Consultancy for sharing their political survey data with us. We also thank Ali Rıza Güngen, Ayşe Nal Akçay, Deniz Sert, Eylem Taylan, three anonymous reviewers for JPS, and the participants of the ERPI 2018 International Conference in The Hague for their helpful critiques and suggestions about this paper. We are thankful to Alper Yıldırım and Alper Şükrü Gençer for their research assistance.

\section{Disclosure statement}

No potential conflict of interest was reported by the authors.

\footnotetext{
${ }^{19}$ As Cihan Tuğal $(2017,226)$ notes,

It is only through the activities of a leading sociopolitical organization that potentially anti-capitalist practices can become and/or remain anti-capitalist. A new benevolent path, therefore, would seek to discover charitable ethics and practices that would enhance the self-organization of the poor (even if the original donors are rich and some of the volunteers are from the propertied classes).
}

Although we think Tuğal underestimates the rich donors' negative influence on solidarity organizations, we entirely agree with him that material solidarity activities should be an indispensable part of anti-capitalist politics. 


\section{ORCID}

Burak Gürel (D) http://orcid.org/0000-0002-1666-8748

\section{References}

Adaman, F., and M. Arsel. 2010. "Globalization, Development, and Environmental Policies in Turkey.' In Understanding the Process of Institutional Change in Turkey: A Political Economy Approach, edited by T. Çetin, and F. Yılmaz, 319-335. New York: Nova Publishers.

Adaman, F., M. Arsel, and B. Akbulut. 2018. "Neoliberal Developmentalism, Authoritarian Populism, and Extractivism in the Countryside: The Soma Mining Disaster in Turkey." Emancipatory Rural Politics Initiative Conference Paper No. 63.

Akçay, Ü, and A. R. Güngen. 2018. Lira's Downfall is a Symptom: The Political Economy of Turkey's Crisis. Accessed October 5, 2018. https://criticalfinance.org/2018/08/18/liras-downfall-is-asymptom-the-political-economy-of-turkeys-crisis/.

Alçın, S. 2017. Tarımda tasfiye politikası! Evrensel. August 31.

Anderson, Leslie E. 2006. "Fascists or Revolutionaries? Left and Right Politics of the Rural Poor." International Political Science Review 27 (2): 191-214.

Arsel, M., B. Akbulut, and F. Adaman. 2015. "Environmentalism of the Malcontent: Anatomy of an Anti-Coal Power Plant Struggle in Turkey." The Journal of Peasant Studies 42 (2): 371-395.

Aydın, Z. 2010. Neo-liberal Transformation of Turkish Agriculture." Journal of Agrarian Change 10 (2): 149-187.

Aytaç, S. E. 2014. "Distributive Politics in a Multiparty System: The Conditional Cash Transfer Program in Turkey." Comparative Political Studies 47 (9): 1211-1237.

Bahçe, S., and A. H. Köse. 2017. "Social Classes and the Neo-Liberal Poverty Regime in Turkey, 20022011." Journal of Contemporary Asia 47 (4): 575-595.

Balkan, N., E. Balkan, and A. Öncü. 2015. The Neoliberal Landscape and the Rise of Islamist Capital in Turkey. New York: Berghahn Books.

Bello, W. 2018. "Counterrevolution, the Countryside and the Middle Classes: Lessons from Five Countries." The Journal of Peasant Studies 45 (1): 21-58.

Borras, S. M. 2019. "Agrarian Social Movements: The Absurdly Difficult but Not Impossible Agenda of Defeating Right-wing Populism and Exploring a Socialist Future." Journal of Agrarian Change (Forthcoming).

Bozkurt-Güngen, S. 2018. "Labour and Authoritarian Neoliberalism Under the AKP Governments in Turkey." South European Society and Politics 23 (2): 219-238.

Butler, D. 2018. With more Islamic Schooling, Erdoğan Aims to Reshape Turkey. January 25. Accessed June 1, 2018. https://www.reuters.com/investigates/special-report/turkey-erdogan-education/.

Büyüktaş, O. 2016. "Tarımda milli çöküş ... Hayati ürünler üretilmiyor." Cumhuriyet, September 15.

Chen, J., J. Pan, and Y. Xu. 2016. "Sources of Authoritarian Responsiveness: A Field Experiment in China." American Journal of Political Science 60 (2): 383-400.

CHP. 2016. "CHP Fındık raporu: "Fındığımıza sahip çıkıyoruz". Accessed January 5, 2018. https://www. chp.org.tr/Public/0/Folder//24374.pdf.

CHP. 2017. Cumhuriyet Halk Partisi bakliyat raporu: "Yozgat tarımına sahip çıkıyoruz". Accessed January 5, 2018. https://www.chp.org.tr/Public/0/Folder//27677.pdf.

Cumhuriyet. Newspaper website. http://www.cumhuriyet.com.tr/.

Çarkoğlu, A. 2017. "Environmental Concerns in Turkey: A Comparative Perspective." In Neoliberal Turkey and its Discontents: Economic Policy and Environment Under Erdoğan, edited by F. Adaman, B. Akbulut, and M. Arsel, 147-174. London and New York: I.B. Tauris.

ÇAYKUR. 2016. Çay Sektörü Raporu 2016. Accessed February 21, 2018. http://www.caykur.gov.tr/ CMS/Design/Sources/Dosya/Yayinlar/142.pdf.

ÇAYKUR. 2018. Accessed February 21, 2018. http://www.caykur.gov.tr/Pages/Kurumsal/ KurumHakkinda.aspx?ltemld=6. 
Demirtaş, S. 2017. Turkey: Toward a More Religious, Less Secular Social Order? August 5. Accessed June 1，2018. http://www.hurriyetdailynews.com/opinion/serkan-demirtas/turkey-toward-amore-religious-less-secular-social-order-116358.

Diken. 2018. AKP'nin özelleştirme karnesi: 14 yılda 60 milyar dolarlık satış yapıldı. April 10. Accessed June 1, 2018. http://www.diken.com.tr/akpnin-ozellestirme-karnesi-14-yilda-60-milyar-dolarliksatis-yapildi/.

Dorlach, T. 2015. "The Prospects of Egalitarian Capitalism in the Global South: Turkish Social Neoliberalism in Comparative Perspective." Economy and Society 44 (4): 519-544.

Dünya. Newspaper website. https://www.dunya.com/.

Duruiz, D. 2015. "Embodiment of Space and Labor: Kurdish Migrant Workers in Turkish Agriculture." In The Kurdish Issue in Turkey: A Spatial Perspective, edited by Z. Gambetti, and J. Jongerden, 289308. London and New York: Routledge.

Ekşi, O. 2006. Bir fındığın içini ... Hürriyet. July 11.

Erboz, F. 2017. "Tarımda korkutan tablo." Yeniçağ, September 13. Accessed January 3, 2018. http:// www.yenicaggazetesi.com.tr/tarimda-korkutan-tablo-172549h.htm.

Ertürk, A. E. 2017. "Ithal cenneti olduk." Sözcü, December 30. Accessed January 3, 2018. http://www. sozcu.com.tr/2017/ekonomi/ithal-cenneti-olduk-2153004/.

Esen, B., and S. Gümüşçü. 2018. "Building a Competitive Authoritarian Regime: State-Business Relations in the AKP's Turkey." Journal of Balkan and Near Eastern Studies 20 (4): 349-372.

Esmer, Y. 2019. "Identity Politics: Extreme Polarization and the Loss of Capacity to Compromise in Turkey." In Democracy Under Threat? A Crisis of Legitimacy, edited by Ursula Van Beek, 121-146. Cham: Palgrave MacMillan.

Evren, E. 2016. "Bir baraj karşıtı mücadelenin yükselişi ve düşüşü: Yusufeli Barajı projesi ve hidrokalkınmanın zaman-mekân siyaseti." In Sudan sebepler, edited by C. Aksu, S. Erensü, and E. Evren, 269-287. İstanbul: İletişim.

Findık-Sen. 2017. Accessed January 3, 2018. https://findiksen.wordpress.com/2017/10/26/findik-sen/. Fiskobirlik. 2017. Accessed December 1, 2017. http://www.fiskobirlik.org.tr/hakkimizda/.

Genç, F. 2016. "Neoliberal dönüşümün çay evresi." In Değişen Karadeniz'i Anlamak, edited by D. Yıldırım and E. Haspolat, 257-280. Ankara: Phoenix.

Grill, J. H. 1982. “The Nazi Party's Rural Propaganda Before 1928." Central European History 15 (2): 149185.

Günaydın, G. 2009. Tarım ve kırsalıkta dönüşüm: Politika transferi süreci AB ve Türkiye. Ankara: Tan Kitabevi.

Günaydın, G. 2016. Türk tarımı böyle tasfiye edildi. August 20. Accessed January 15, 2017. https:// www.karasaban.net/turk-tarimi-boyle-tasfiye-edildi-gokhan-gunaydin/.

Gürel, B. 2014. "Türkiye'de kırda sınıf mücadelelerinin tarihsel gelişimi." In Marksizm ve Sınıflar: Dünyada ve Türkiye'de sınıflar ve mücadeleleri, edited by S. Savran, E. A. Tonak, and K. Tanyılmaz, 303-385. İstanbul: Yordam.

Gürel, B. 2018. The Third Great Depression and the Rise of the Far-Right: Experiences from Turkey. April 25. Accessed April 25, 2018. https://www.opendemocracy.net/burak-g-rel/third-greatdepression-and-rise-of-far-right-experiences-from-turkey.

Güven, A. B. 2009. "Reforming Sticky Institutions: Persistence and Change in Turkish Agriculture." Studies in Comparative International Development 44 (2): 162-187.

Güven, A. B. 2016. "Rethinking Development Space in Emerging Countries: Turkey's Conservative Movement." Development and Change 47 (5): 995-1024.

Haberler.com. 2010. December 21. Accessed October 5, 2018. https://www.haberler.com/loc-vadisikoylulerinden-hes-e-destek-2428319-haberi/.

Hak İnisiyatifi İstanbul. 2018. Olağanüstü hal koşullarında grev hakkı raporu. April 23. Accessed October 5, 2018. https://hakinisiyatifi.net/wp-content/uploads/2018/05/HAKinisiyatifi_OHALde_ Grev_Raporu.pdf.

Halkevleri. 2010. 'Tarım, gıda egemenliği, beslenme hakkı' atölyesi çağrısı. Accessed January 5, 2017. http://www.halkevleri.org.tr/bilim-arastirma/tarim-gida-egemenligi-beslenme-hakki-atolyesicagrisi. 
Hamsici, M. 2011. Dereler ve isyanlar. 2nd ed. Ankara: NotaBene.

Hürriyet. Newspaper website. http://www.hurriyet.com.tr/.

Ince, S. 2012. Fındık üreticisi AKP'ye mecbur mu? Birgün-Pazar. August 19.

Karpat, B. 2006. "Fiskobirlik gerçekleri." Birgün, July 11.

Keyder, Ç, and Z. Yenal. 2013. Bildiğimiz tarımın sonu: Küresel iktidar ve köylülük. Istanbul: Illetişim.

Keyman, E. F. 2014. "The AK Party: Dominant Party, New Turkey, and Polarization." Insight Turkey 16 (2): 19-31.

KONDA. 2007-2017. KONDA Barometer Surveys.

Milliyet. Newspaper website. http://www.milliyet.com.tr/.

ÖDP (Özgürlük ve Dayanışma Partisi). 2017. 15 Yılda tarımda yıkım raporu: Tarımda yıkıma, yağmaya, talana hayır. Accessed December 8, 2017. http://portal.odp.org.tr/wp-content/uploads/2017/03/ TARIMRAPOR.pdf.

OECD. 2018a. OECD Data. Accessed January 5, 2017. https://data.oecd.org/agrpolicy/agriculturalsupport.htm\#indicator-chart.

OECD. 2018b. OECD.Stat. Accessed June 1, 2017. http://stats.oecd.org/lndex.aspx?datasetcode= SOCX_AGG.

Öniş, Z. 2012. "The Triumph of Conservative Globalism: The Political Economy of the AKP Era." Turkish Studies 13 (2): 135-152.

Oral, N. 2010. Tarımda doğrudan gelir desteği bitti, sıra havza bazlı modelde. January 12. Accessed March 17, 2016. https://m.bianet.org/biamag/tarim/119405-tarimda-dogrudan-gelir-destegi-bittisira-havza-bazli-modelde.

Oral, N., ed. 2013. Türkiye'de tarımın ekonomi-politiği 1923-2013. İstanbul: Notabene.

Paxton, R. O. 1997. French Peasant Fascism: Henry Dorgères's Greenshirts and the Crisis of French Agriculture, 1929-1939. Oxford: Oxford University Press.

Paxton, R. O. 1998. "The Five Stages of Fascism." The Journal of Modern History 70 (1): 1-23.

Pazar53. 2009. HES'e destek, basına tepki. May 22. Accessed October 5, 2018. http://www.pazar53. com/hese-destek,-basina-tepki-11580h.htm.

Pelek, D. 2010. "Seasonal Migrant Workers in Agriculture: The Case of Ordu and Polatlı." Master's thesis., Boğaziçi University, Atatürk Institute for Modern Turkish History, İstanbul.

Ramírez, V. 2017. "Wellbeing and Relationships in Public Policy: The Officer-Recipient Relationship in the Oportunidades-Prospera Programme in Mexico." Ph.D. thesis., University of Bath, Bath.

Sabah. Newspaper website. https://www.sabah.com.tr/.

Scoones, I. 2018. Ongoing Conversations: Realising an Emancipatory Rural Politics in the Face of an Authoritarian Populism. March 24. Accessed March 29, 2018. https://www.opendemocracy.net/ ian-scoones/ongoing-conversations-realising-emancipatory-rural-politics-in-face-of-authoritarianpop.

Scoones, I., M. Edelman, S. M. Borras Jr, R. Hall, W. Wolford, and B. White. 2018. "Emancipatory Rural Politics: Confronting Authoritarian Populism." The Journal of Peasant Studies. doi:10.1080/ 03066150.2017 .1339693

Somer, M. 2016. “Understanding Turkey's Democratic Breakdown: Old vs. New and Indigenous vs. Global Authoritarianism." Southeast European and Black Sea Studies 16 (4): 481-503.

T.C. Gıda, Tarım ve Hayvancılık Bakanlığı. 2017. Çay işletmeleri verileri. Accessed June 1, 2018. https:// www.tarim.gov.tr/sgb/Belgeler/SagMenuVeriler/CAYKUR.pdf.

T.C. Gümrük ve Ticaret Bakanlığı Kooperatifçilik Genel Müdürlüğü. 2017. 2016 Yılı Fındık Raporu. Ankara: T.C. Gümrük ve Ticaret Bakanlığı.

The Economist. 2018. Turkey's Religious Authority Surrenders to Political Islam. January 18. Accessed June 1, 2018. https://www.economist.com/europe/2018/01/18/turkeys-religious-authoritysurrenders-to-political-islam.

TKP (Türkiye Komünist Partisi). 2007. Seçim Bildirgesi.

Torul, O., and O. Öztunalı. 2018. "On income and wealth inequality in Turkey." Central Bank Review. doi:10.1016/j.cbrev.2018.06.002.

Tuğal, C. 2017. Caring for the Poor: Islamic and Christian Benevolence in a Liberal World. London and New York: Routledge. 
Turkish Statistical Institute. 2012. General Election of Representatives Province and District Results 2011, 2007, 2002, 1999, 1995, 1991. Ankara: Turkish Statistical Institute.

Turkish Statistical Institute. 2016. Basın odası haberleri. November 8. Accessed February 7, 2017. http://www.tuik.gov.tr/basinOdasi/haberler/2016_112_20161108.pdf.

Turkish Statistical Institute. 2018. Temel İstatistikler. Accessed October 5, 2018. http://www.tuik.gov. tr/UstMenu.do?metod=temelist.

World Bank. 2018. World Bank Open Data. Accessed January 5, 2018. https://data.worldbank.org/.

Yazan, A. 2018. Seçim 2018: Karadeniz'in can damarı fındık sandığa ne kadar yansır? June 17. Accessed October 5, 2018. https://www.bbc.com/turkce/haberler-turkiye-44511790.

Yetkin, M. 2017. "The First Survey after Turkey's Polls Gives Striking Results." Hürriyet Daily News, April 20.

Yıldıım, A. E. 2007. Fiskobirlik yönetimi AKP'ye geçti. December 5. Accessed May 7, 2016. http://www. aliekberyildirim.com/2007/12/05/fiskobirlik-yonetimi-akpye-gecti-2/.

Yıldııım, A. E. 2014. "Cumhuriyet'in 100. yılına doğru, yeni tarım düzeni ...." Dünya, December 10.

Yıldıım, A. E. 2017a. "Tarımda girdi odaklı destekleme modeline geçilecek." Dünya, February 2.

Yıldırım, A. E. 2017b. "Devletin fındığa müdahalesi." Dünya, April 20.

Yıldııım, A. E. 2017c. "Fındıkta şirket egemenliği." Dünya, September 7.

Yörük, E. 2012. "Welfare Provision as Political Containment: The Politics of Social Assistance and the Kurdish Conflict in Turkey." Politics and Society 40 (4): 517-547.

Burak Gürel is an assistant professor in the Department of Sociology at Koç University. He holds a $\mathrm{PhD}$ in sociology from Johns Hopkins University. His scholarly interests include political economy, historical sociology, rural development, social movements and welfare politics, with a focus on China, India and Turkey. Email: bgurel@ku.edu.tr.

Bermal Küçük is a Ph.D. student in the Department of Sociology at Koç University. Her research interests are rural development, sociology of food and political ecology, with a focus on the labor and knowledge of women. Email: bkucuk16@ku.edu.tr.

Sercan Taş is a Ph.D. student in the Department of Sociology at Koç University. His research interests include rural development, urbanization, and environmental governance, with a focus on Turkey. Email: stas17@ku.edu.tr. 